\title{
Research on semi-precast prestressed concrete slab under short-term and long-term load
}

\author{
Jakub Zając ${ }^{1 *}$, Eukasz Drobiec ${ }^{1}$, Radosław Jasiński ${ }^{1}$, Wojciech Mazur ${ }^{1}$, Krzysztof Grzyb ${ }^{1}$ \\ and Artur Kisiołek ${ }^{2}$ \\ ${ }^{1}$ Silesian University of Technology, Department of Building Structures, Akademicka 5, 44-100 \\ Gliwice, Poland \\ ${ }^{2}$ Wielkopolska Higher School of Social Sciences and Economics, Institute of Economics, \\ Surzyńskich 2, 63-000 Środa Wielkopolska, Poland
}

\begin{abstract}
Tests of a full-scale model of slab with the dimensions of $6.30 \times 6.30 \mathrm{~m}$, built of TerivaPanel panels were carried out under short-term and long-term load. TerivaPanel panels are partial precast, pre-tensioned concrete slabs with ribs connected at the bottom. The panels have a specially shaped cross-connection (shear key) enabling loads to be transferred between the panels. The tests were carried out under a load placed on the top of the slab. Additionally, the load was applied sequentially. Measurements were made by an electronic method. In one of the stages, long-term testing, the load was applied to one half of the slab to examine the possibility of faulting. The measurements were carried out at monthly intervals, using a geodetic method. The values of vertical displacements at the panel joints (in the middle of the slab) and for central panels along the entire length of the joint were measured.
\end{abstract}

\section{Introduction}

Short-term and long-term field tests of TerivaPanel slab belonging to the family of solutions referred to as panel slabs were carried out. Behind the name "panel slabs" there are several basic features: flat bottom surface of the elements used as the lost formwork with the main load-bearing reinforcement, modular width of $600 \mathrm{~mm}$ and the possibility of laying the panels with a light HDS crane [1]. The basic element of the TerivaPanel slab is a partially precast, pre-tensioned panel referring to already existing precast solutions such as TT crosssection panels, precast ribbed panels or hollow-core panels which have been produced for over 40 years [2]. The precast TerivaPanel slab element is a double-ribbed $600 \mathrm{~mm}$ wide panel with ribs in a $350 \mathrm{~mm}$ axial spacing, produced with a lightweight concrete filling between the ribs. The whole panel is a stay-in-place formwork for the cast in-place concrete topping. This design allows for significant acceleration of construction process due to fewer supports and elimination of the additional reinforcement at the joints of the panels [3]. Rib elements with a common bottom plate are currently more and more popular constructions and are actively developed [4]. Researches are mainly focused on concrete topping and

\footnotetext{
* Corresponding author: Jakub.Zajac@polsl.pl
} 
longitudinal shear [5]. The shape of the shear-key created between neighbouring TerivaPanel panels is designed to take over transverse forces (without having to reinforce joints) and redistribute the loads to the adjacent precast panels, as in other precast solutions [6-8]. This, in turn, allows engineering calculations to take into account the transverse cooperation of precast elements [7]. Due to prestressing the ribs, it is possible to reduce the number of temporal supports, and with spans $<4.0 \mathrm{~m}$ the supports can be eliminated. The lightweight filling in the slab can be replaced on the construction site with concrete to increase the shear capacity, similar to solutions used in hollow-core slabs [9-10] or beam and block slabs. The necessity to make a concrete topping thickness of min. $40 \mathrm{~mm}$ over the entire surface of the slab allows the use of upper support reinforcement. The thickness of the concrete topping results from the calculation concerning the take-over of positive span moments or negative support moments [11].

\section{Description of the research}

The purpose of the research was to observe the behaviour of the TerivaPanel slabs under short-term and long-term loads. Particular attention was paid to vertical displacements, including mutual displacements of panels - the effect of faulting and morphology of cracks.

\subsection{Construction of the research model}

Tests of a full-scale model of slab, built of TerivaPanel panels were carried out under short-term and long-term load. Precast concrete (C40/50) TerivaPanel panels consisting of a concrete bottom plate $40 \mathrm{~mm}$ thick and $600 \mathrm{~mm}$ wide with upwardly shaped two longitudinal ribs $120 \mathrm{~mm}$ high with an axial spacing of $350 \mathrm{~mm}$ were used. The prestressing reinforcement of the ribs consisted of a 7-wire $\phi 6.85 \mathrm{~mm}$ strand of Y2060S7 steel, placed in accordance with Fig. 1. In each precast panel, the spaces between the ribs were filled with lightweight $80 \mathrm{~mm}$ thick concrete, and after the assembly of elements, a $40 \mathrm{~mm}$ layer of concrete topping $(\mathrm{C} 25 / 30)$ was made. The whole construction was $160 \mathrm{~mm}$ thick. The research model was made in the form of a spatial structure measuring $\sim 6.30 \times 6.30 \mathrm{~m}$ based on walls made of concrete blocks $240 \mathrm{~mm}$ thick and $2.20 \mathrm{~m}$ high (Fig. 2).

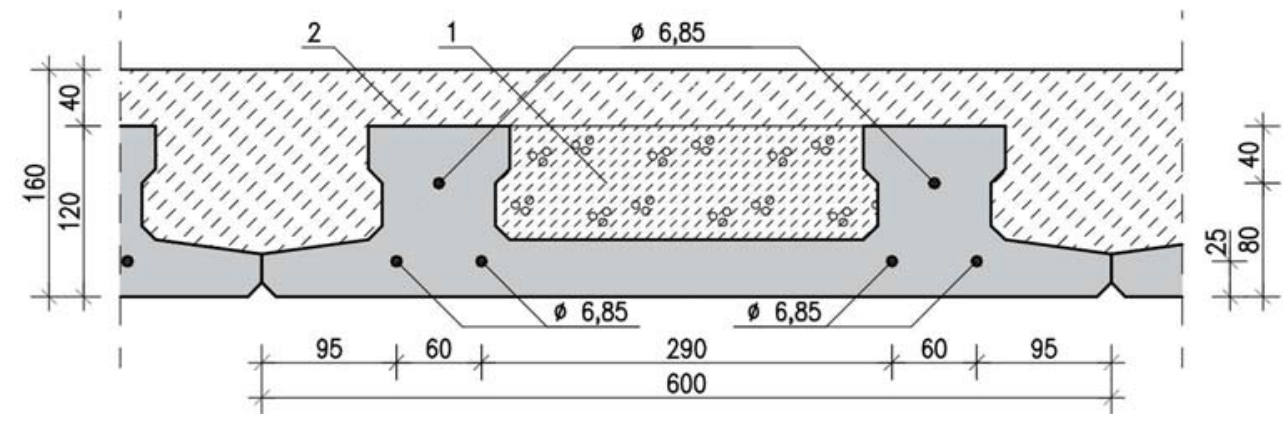

Fig. 1. Cross-section of the slab with panels: 1- lightweight concrete, 2- concrete topping 
a)

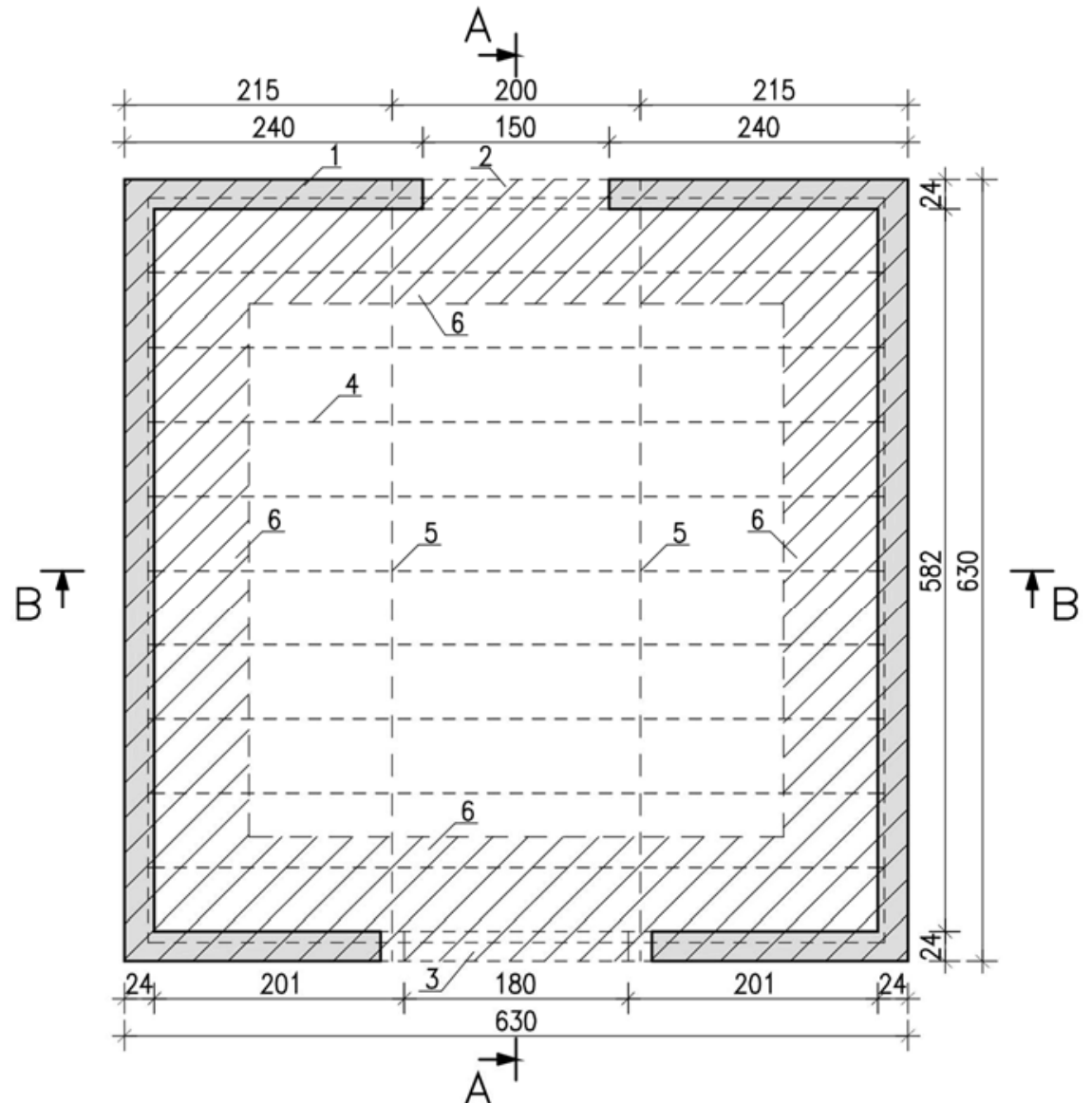

b)

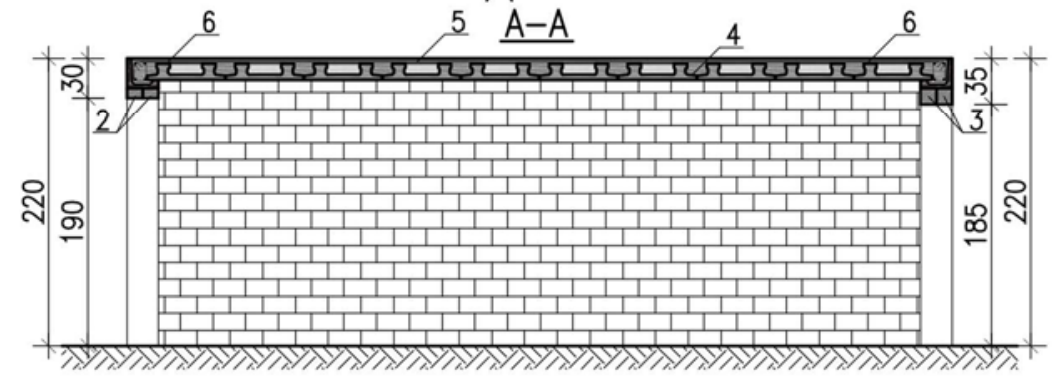

c)

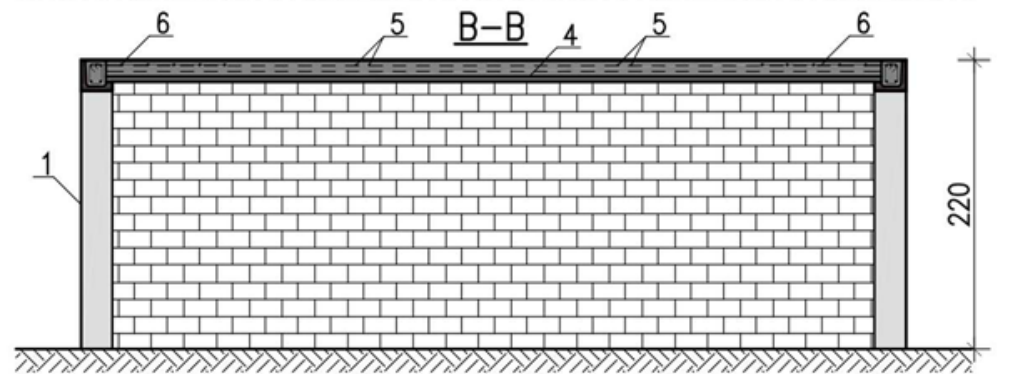

Fig. 2. Geometric dimensions: a) top view b) A-A cross-section, c) B-B cross-section (1- wall of concrete blocks, 2- lintel $2 \times$ SBN 7,2/12/210, 3- lintel $2 \times$ SBN 12/12/180, 4- TerivaPanel, 5- distribution ribs, 6- support reinforcement) 
In the support zone, a reinforcing mesh with a diameter of $\varnothing 4 \mathrm{~mm}$ and a spacing of $200 \mathrm{~mm}$ was laid, $1.0 \mathrm{~m}$ wide from the outer edge of the floor slab (Fig. 3). Two distribution ribs of two $\emptyset 10 \mathrm{~mm}$ bars located on the panel ribs were made along the panel width, in accordance with slab technical documentation [11].

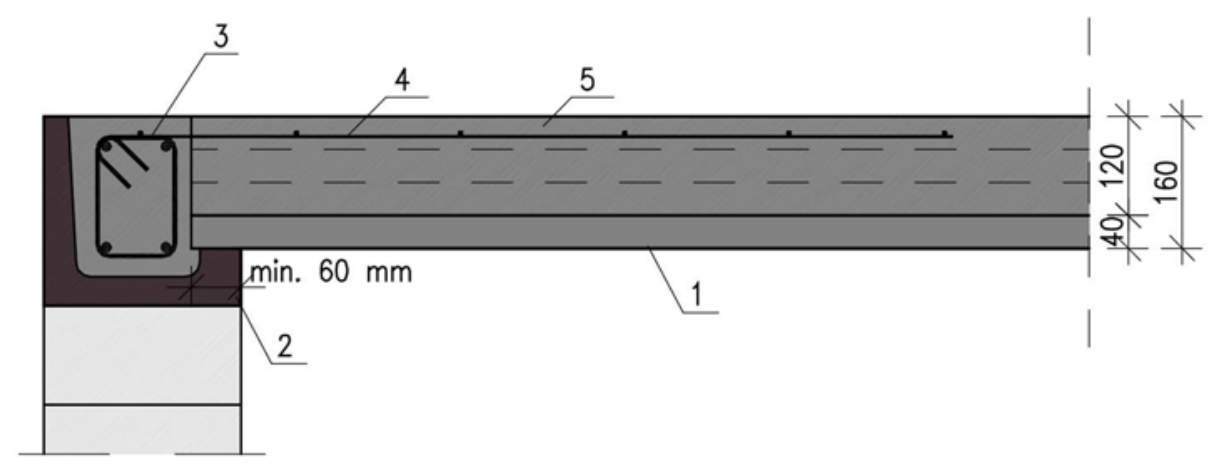

Fig. 3. Details of reinforcement of the support zone: 1- TerivaPanel, 2- tie-beam precast form, 3- tiebeam 240x220 mm, 4- support reinforcement $\emptyset 4$ 200x200/1000x2000 mm, 5- concrete topping

Fig. 4 shows the successive stages of preparing the test model, Fig. 4a the assembly of precast panels, while Fig. 4b the reinforcement of the support zones. Fig. $4 \mathrm{c}$ shows the measuring system located at the bottom of the slab and Fig. 4d the final load stage left for long-term tests, scheduled for 12 months.

a)

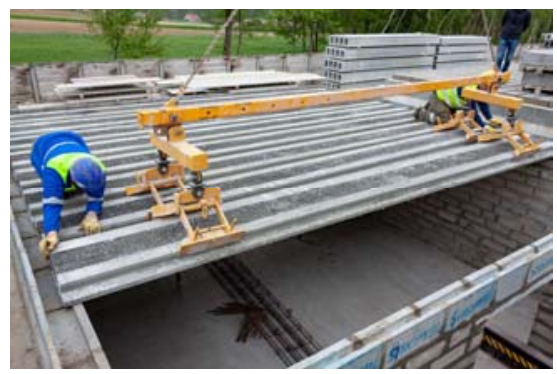

c)

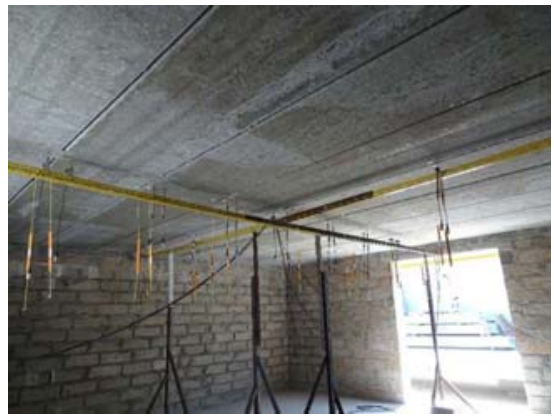

b)

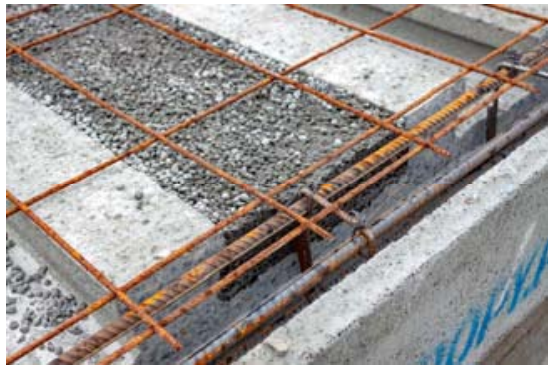

d)

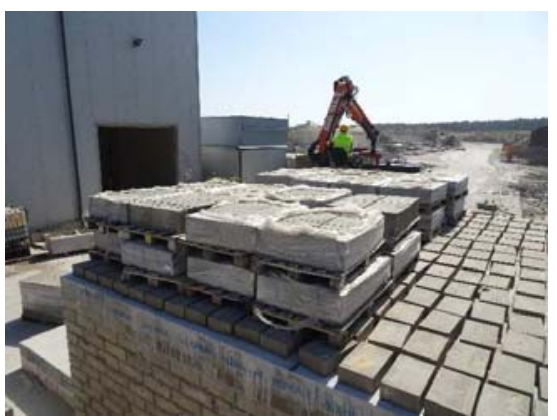

Fig. 4. Research model: a) panel laying, b) support reinforcement, c) inductive and geodetic sensors, d) long-term load 


\subsection{Measuring equipment}

Short-term displacements were recorded using linear displacement transducers (LVDT) type PJX-10 and PJX-20 with an indication accuracy of $0.002 \mathrm{~mm}$. The sensors were attached to a steel frame based on a reinforced concrete floor. Fig. 5 shows the arrangement of the sensors along the axis of the door openings and along the joint of the central panels (panels 5 and 6 ). The sensors were placed $\sim 25 \mathrm{~mm}$ from the panel joint, the distance between adjacent sensors was $\sim 50 \mathrm{~mm}$. Additional markers for geodetic measurements were located from the bottom of the slab, next to the electronic sensors. The geodetic measurement was used to read displacements from long-term loads using optical leveller, measuring patch with a millimetre scale. The measurement accuracy of displacements from long-term loads was $+/-0.5 \mathrm{~mm}$.

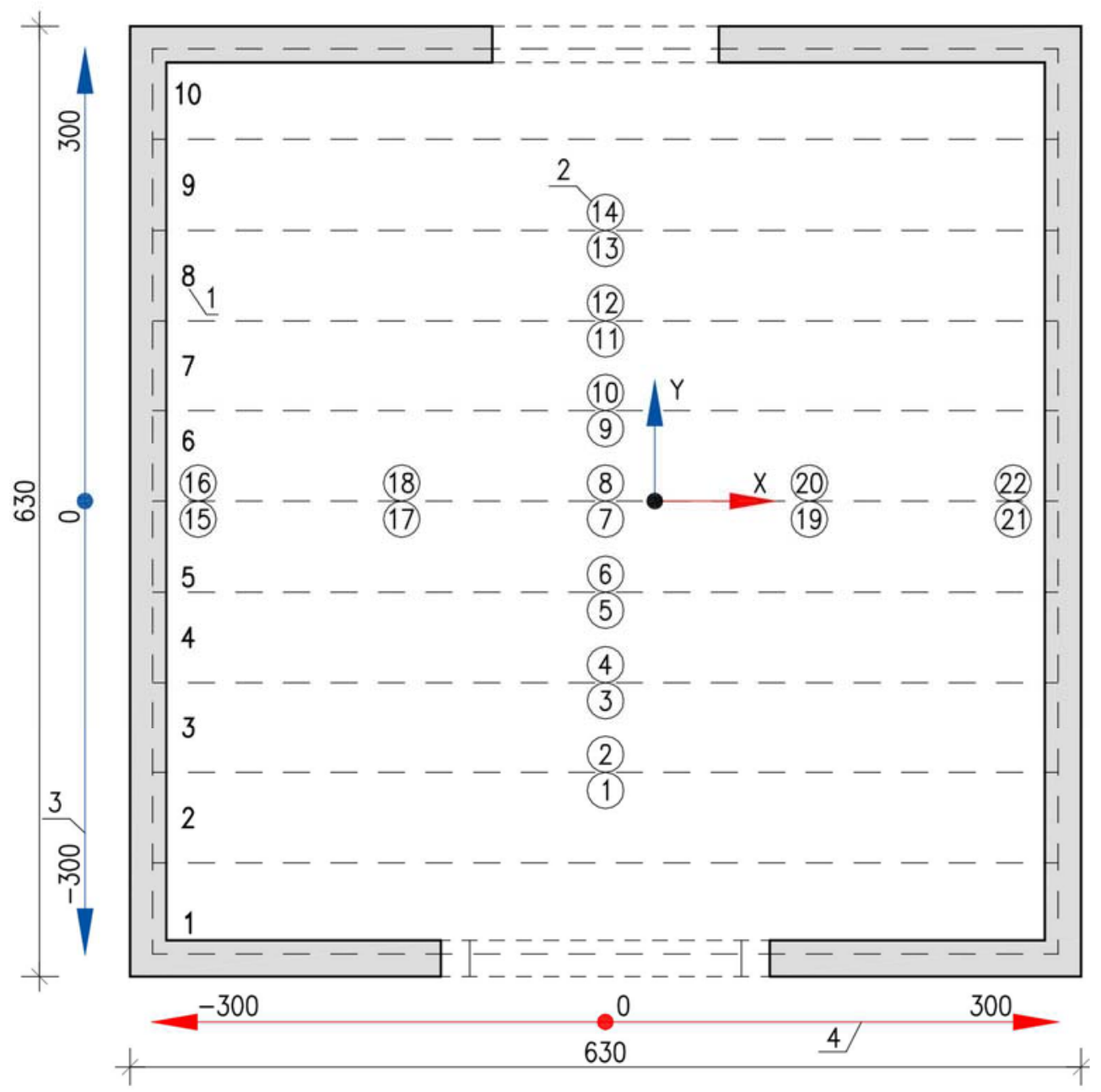

Fig. 5. Arrangement of the transducer and geodetic sensors for measuring vertical displacements on the lower surfaces of the tested slabs: 1- plate number, 2- sensor number, 3- measurement direction transverse to the main direction of the panels (Y-axis), 4- measurement direction along the length of the central panels' joint (X-axis) 


\subsection{Application method and load schedule}

The research model was loaded gravitationally, according to a schedule. Single concrete blocks (350x250x120 mm) and blocks stacked on pallets were used to induce loads. The total load over the slab's own weight of $4.7 \mathrm{kN} / \mathrm{m}^{2}$ was divided into two parts $1.7 \mathrm{kN} / \mathrm{m}^{2}$ (concrete blocks laid on the upper surface of the slab) and $3.0 \mathrm{kN} / \mathrm{m}^{2}$ (pallets with concrete blocks laid on the previously laid concrete blocks). The load application schedule is shown in Fig. 6. Automatic displacements registering was made after 15 minutes from the moment the load is placed. Schemes F and L were a continuation of previous schemes E and K, with the displacement registering taken after an hour's break. Scheme L was left for long-term studies (see Fig. 4d). Long-term deflection and faulting tests are scheduled to proceed for 12 months.

Scheme A - 1

\begin{tabular}{|c|c|}
\hline $\begin{array}{c}0,0 \\
\mathrm{kN} / \mathrm{m}^{2}\end{array}$ & $\begin{array}{c}0,0 \\
\mathrm{kN} / \mathrm{m}^{2}\end{array}$ \\
\hline $\begin{array}{c}0,0 \\
\mathrm{kN} / \mathrm{m}^{2}\end{array}$ & $\begin{array}{c}0,0 \\
\mathrm{kN} / \mathrm{m}^{2}\end{array}$ \\
\hline
\end{tabular}

Scheme E - 5

\begin{tabular}{|c|c|}
\hline $\begin{array}{c}1,7 \\
\mathrm{kN} / \mathrm{m}^{2}\end{array}$ & $\begin{array}{c}1,7 \\
\mathrm{kN} / \mathrm{m}^{2}\end{array}$ \\
\hline $\begin{array}{c}1,7 \\
\mathrm{kN} / \mathrm{m}^{2}\end{array}$ & $\begin{array}{c}1,7 \\
\mathrm{kN} / \mathrm{m}^{2}\end{array}$ \\
\hline
\end{tabular}

Scheme I - 9

\begin{tabular}{|c|c|}
\hline $\begin{array}{c}4,7 \\
\mathrm{kN} / \mathrm{m}^{2}\end{array}$ & $\begin{array}{c}4,7 \\
\mathrm{kN} / \mathrm{m}^{2}\end{array}$ \\
\hline $\begin{array}{c}4,7 \\
\mathrm{kN} / \mathrm{m}^{2}\end{array}$ & $\begin{array}{c}1,7 \\
\mathrm{kN} / \mathrm{m}^{2}\end{array}$ \\
\hline
\end{tabular}

Scheme B - 2

\begin{tabular}{|c|c|}
\hline $\begin{array}{c}1,7 \\
\mathrm{kN} / \mathrm{m}^{2}\end{array}$ & $\begin{array}{c}0,0 \\
\mathrm{kN} / \mathrm{m}^{2}\end{array}$ \\
\hline $\begin{array}{c}0,0 \\
\mathrm{kN} / \mathrm{m}^{2}\end{array}$ & $\begin{array}{c}0,0 \\
\mathrm{kN} / \mathrm{m}^{2}\end{array}$ \\
\hline
\end{tabular}

Scheme F - 6

\begin{tabular}{|c|c|}
\hline $\begin{array}{c}1,7 \\
\mathrm{kN} / \mathrm{m}^{2}\end{array}$ & $\begin{array}{c}1,7 \\
\mathrm{kN} / \mathrm{m}^{2}\end{array}$ \\
\hline $\begin{array}{c}1,7 \\
\mathrm{kN} / \mathrm{m}^{2}\end{array}$ & $\begin{array}{c}1,7 \\
\mathrm{kN} / \mathrm{m}^{2}\end{array}$ \\
\hline
\end{tabular}

Scheme J - 10

\begin{tabular}{|c|c|}
\hline $\begin{array}{c}4,7 \\
\mathrm{kN} / \mathrm{m}^{2}\end{array}$ & $\begin{array}{c}4,7 \\
\mathrm{kN} / \mathrm{m}^{2}\end{array}$ \\
\hline $\begin{array}{c}4,7 \\
\mathrm{kN} / \mathrm{m}^{2}\end{array}$ & $\begin{array}{c}4,7 \\
\mathrm{kN} / \mathrm{m}^{2}\end{array}$ \\
\hline
\end{tabular}

Scheme C - 3

\begin{tabular}{|c|c|}
\hline $\begin{array}{c}1,7 \\
\mathrm{kN} / \mathrm{m}^{2}\end{array}$ & $\begin{array}{c}1,7 \\
\mathrm{kN} / \mathrm{m}^{2}\end{array}$ \\
\hline $\begin{array}{c}0,0 \\
\mathrm{kN} / \mathrm{m}^{2}\end{array}$ & $\begin{array}{c}0,0 \\
\mathrm{kN} / \mathrm{m}^{2}\end{array}$ \\
\hline
\end{tabular}

Scheme G - 7

\begin{tabular}{|c|c|}
\hline $\begin{array}{c}4,7 \\
\mathrm{kN} / \mathrm{m}^{2}\end{array}$ & $\begin{array}{c}1,7 \\
\mathrm{kN} / \mathrm{m}^{2}\end{array}$ \\
\hline $\begin{array}{c}1,7 \\
\mathrm{kN} / \mathrm{m}^{2}\end{array}$ & $\begin{array}{c}1,7 \\
\mathrm{kN} / \mathrm{m}^{2}\end{array}$ \\
\hline
\end{tabular}

Scheme K - 11

\begin{tabular}{|c|c|}
\hline $\begin{array}{c}7,7 \\
\mathrm{kN} / \mathrm{m}^{2}\end{array}$ & $\begin{array}{c}7,7 \\
\mathrm{kN} / \mathrm{m}^{2}\end{array}$ \\
\hline $\begin{array}{c}1,7 \\
\mathrm{kN} / \mathrm{m}^{2}\end{array}$ & $\begin{array}{c}1,7 \\
\mathrm{kN} / \mathrm{m}^{2}\end{array}$ \\
\hline
\end{tabular}

Scheme D - 4

\begin{tabular}{|c|c|}
\hline $\begin{array}{c}1,7 \\
\mathrm{kN} / \mathrm{m}^{2}\end{array}$ & $\begin{array}{c}1,7 \\
\mathrm{kN} / \mathrm{m}^{2}\end{array}$ \\
\hline $\begin{array}{c}1,7 \\
\mathrm{kN} / \mathrm{m}^{2}\end{array}$ & $\begin{array}{c}0,0 \\
\mathrm{kN} / \mathrm{m}^{2}\end{array}$ \\
\hline
\end{tabular}

Scheme $\mathrm{H}-8$

\begin{tabular}{|c|c|}
\hline $\begin{array}{c}4,7 \\
\mathrm{kN} / \mathrm{m}^{2}\end{array}$ & $\begin{array}{c}4,7 \\
\mathrm{kN} / \mathrm{m}^{2}\end{array}$ \\
\hline $\begin{array}{c}1,7 \\
\mathrm{kN} / \mathrm{m}^{2}\end{array}$ & $\begin{array}{c}1,7 \\
\mathrm{kN} / \mathrm{m}^{2}\end{array}$ \\
\hline
\end{tabular}

Scheme L - 12

\begin{tabular}{|c|c|}
\hline $\begin{array}{c}7,7 \\
\mathrm{kN} / \mathrm{m}^{2}\end{array}$ & $\begin{array}{c}7,7 \\
\mathrm{kN} / \mathrm{m}^{2}\end{array}$ \\
\hline $\begin{array}{c}1,7 \\
\mathrm{kN} / \mathrm{m}^{2}\end{array}$ & $\begin{array}{c}1,7 \\
\mathrm{kN} / \mathrm{m}^{2}\end{array}$ \\
\hline
\end{tabular}

Fig. 6. Load schemes with steps numbers

\section{Results of experimental research}

The results of the research in the form of graphs showing the displacement of the sensors indicated in Fig. 5 for the short and long-term situations are shown in Fig. 8 - Fig. 11. The results of short-term tests include displacement differences between adjacent sensors, i.e. on the edges of the panels in contact. The colour of the graphs corresponds to the colours of the lines marked with numbers 3 and 4 - Y-axis and X-axis (see Fig. 5) showing vertical displacements for the transverse joint direction (panels No. $2-9$ ) and longitudinal joint in the case of central panels No. 5 and 6. 


\subsection{Effects of short-term load}

Fig. 8 shows the displacement results for the sensors in the opening axis in each of the load steps. After transferring a part of the load from 1-5 to 6-10 panels (after step J), reduced displacements in the first part of the slab were measured. The displacement difference between adjacent sensors $\Delta u$ was a maximum of $0.49 \mathrm{~mm}$ (Fig. 9). The value of the difference increased in each of the sensor pairs, throughout the entire process of conducting research under immediate load. Before the tests and after each load step, observations of cracks on the bottom surface were made. When conducting tests under short-term load, no cracks were observed.

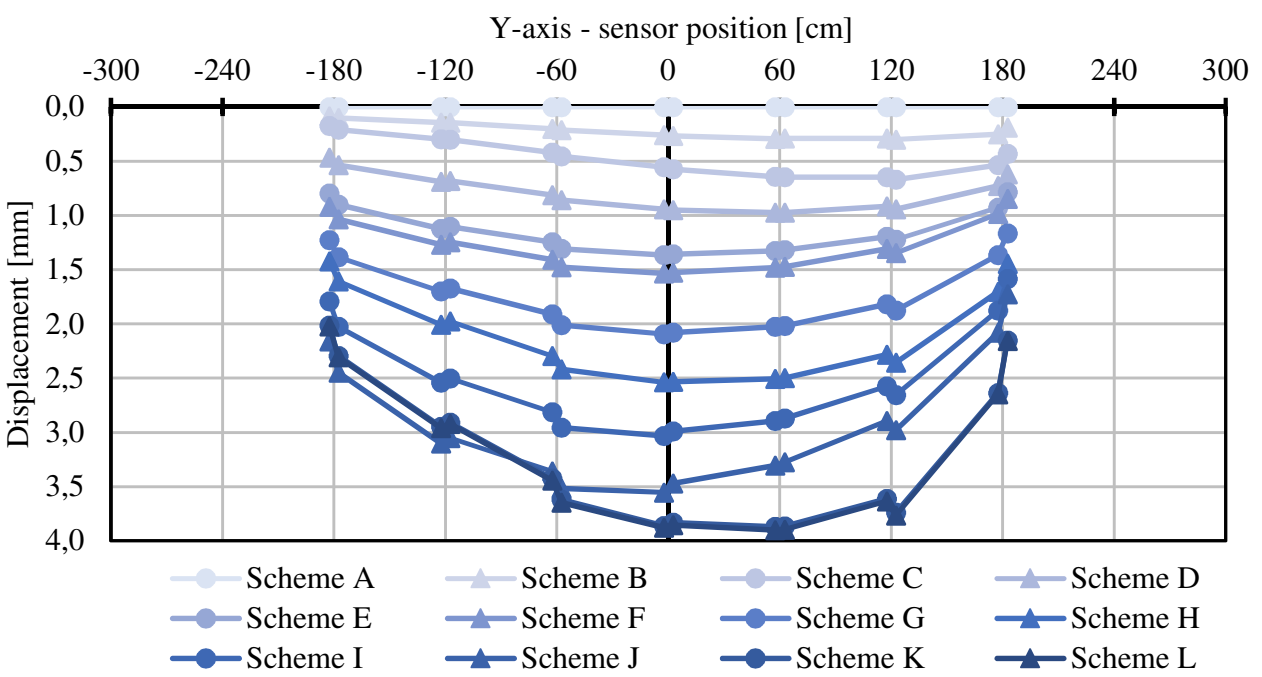

Fig. 8. Displacements in the following load steps

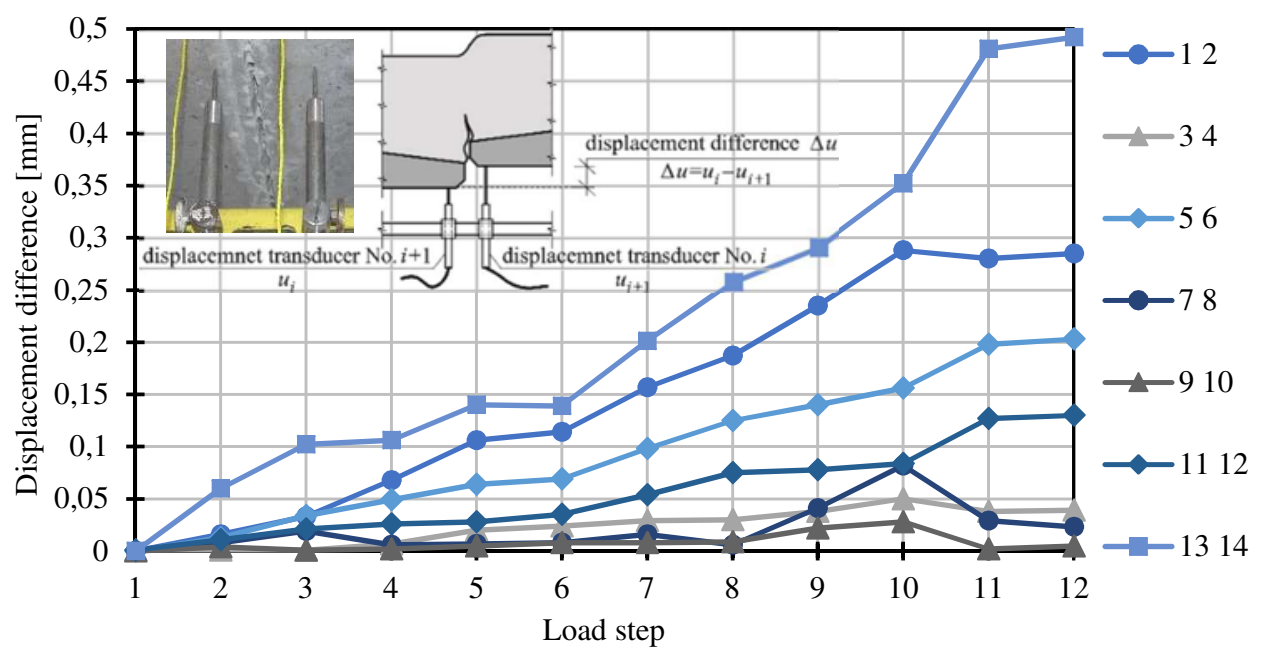

Fig. 9. Displacement difference between two adjacent sensors 


\subsection{Effects of long-term load}

Long-term tests were planned to be carried out for 12 months under a constant load corresponding to the $\mathrm{L}$ scheme $\left(7.7 \mathrm{kN} / \mathrm{m}^{2}\right.$ and $1.7 \mathrm{kN} / \mathrm{m}^{2}$ divided into two parts on the slab - Fig. 6). The frequency of geodetic displacement measurements is planned to be carried out every 30-45 days. Fig. 10 shows selected results of long-term measurements starting from the measurement taken 24 hours from the start of the tests. After a period of 7 months, the maximum displacement of the slab is $11.0 \mathrm{~mm}$, which was an increase of $282 \%$ compared to the last short-term measurement and $83 \%$ compared to the one taken 24 hours after applying the load. Under the influence of long-term effects, panels No. 6-10, gravity loaded to a value of $7.7 \mathrm{kN} / \mathrm{m}^{2}$ over their weight, showed almost twice the increase in displacement than panels No. $1-5\left(\operatorname{load}\right.$ of $\left.1.7 \mathrm{kN} / \mathrm{m}^{2}\right)$. The exact displacement values of sensor No. 5 (panel No. 4) were $~ 3.5 \mathrm{~mm}$ (Fig. 8) and $7 \mathrm{~mm}$ (increase by $3.5 \mathrm{~mm}$ ), and sensor No. 10 (panel No. 7) $4 \mathrm{~mm}$ (Fig. 8) and $10 \mathrm{~mm}$ (increase by $6 \mathrm{~mm}$ ).

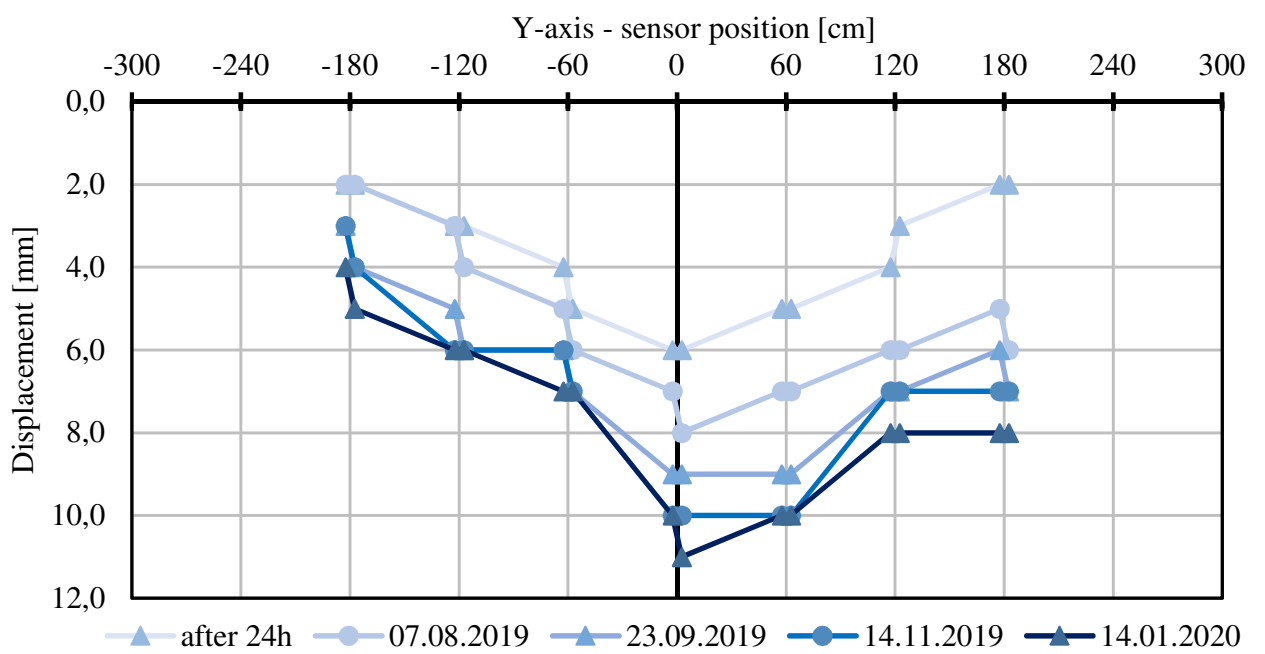

Fig. 10. Displacement in the following months

Fig. 11 shows the vertical displacement values of the measuring for the points on the edge of the middle panels (No. 5 and 6), made after $24 \mathrm{~h}$ and also 7 months from the start of the study. The initial symmetry of the plate displacements to the centre of the span changed with the time of load influence. Recent measurements showed displacements of sensors No. 1718 larger by $4 \mathrm{~mm}$ than those of a pair of sensors 19-20.

Regardless of the load step and the place of measurement (pair of sensors), the difference in displacement $\Delta \mathrm{u}$ between two adjacent sensors increased but didn't exceed $1 \mathrm{~mm}$. Continuous inspection of the bottom surface of the slab showed no cracks. Full inventory of slab cracks, with the upper surface and possible delamination (by taking cores) is planned after the completion of long-term tests. 


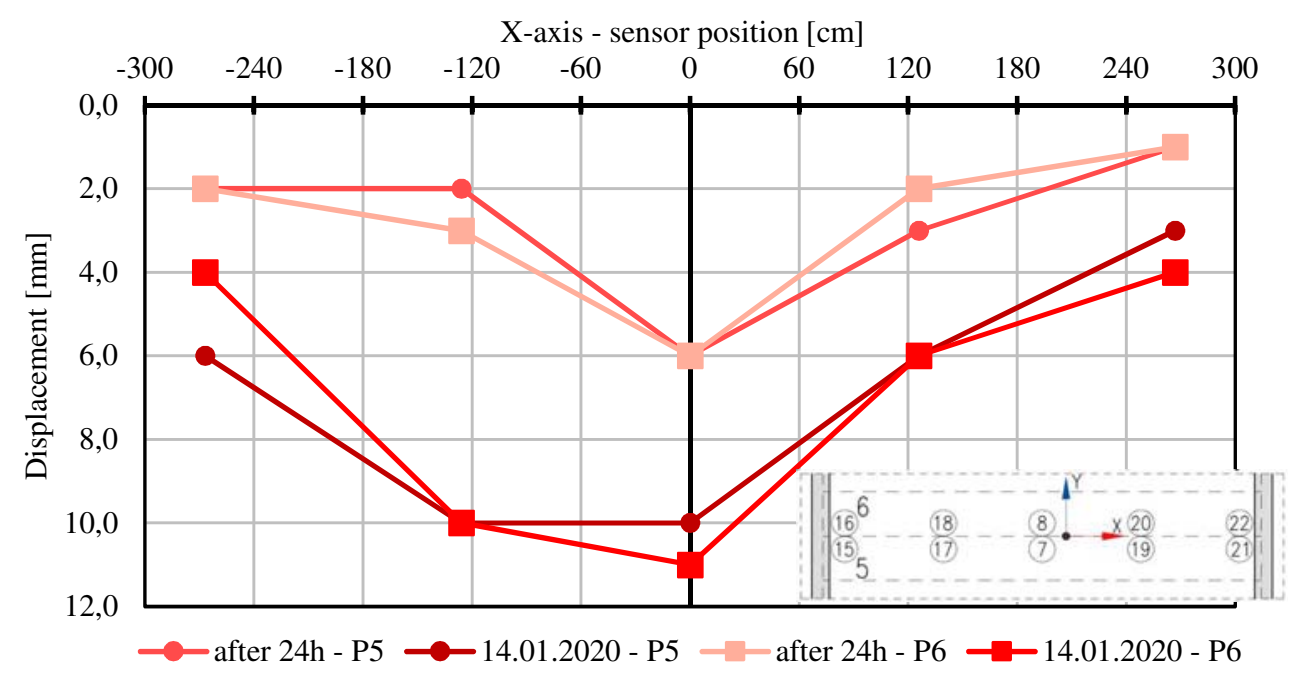

Fig. 11. Displacement at the centre panels joint

\section{Discussion of the results}

The characteristic of displacements in two perpendicular directions undoubtedly confirms the two-way work of the slab, even in the absence of transverse reinforcement of panels and joints. This gives ground to conclude that the shape of the joint (shear-key) between the panels, connected with concrete topping, allows the transfer of shear forces between panels in the range resulting from the applied load and the geometry of the slabs. Due to the lack of visible cracks, it can be stated that the slabs under short-term load worked in an uncracked condition. Theoretically speaking, minute cracks could be invisible and some cracks may have formed between the prefabricated element and the concrete topping in the tension zone of the joint.

The values of vertical displacements were much smaller than in the linear-elastic computational model of the one-way panels, which is adopted at the design stage. The practice of treating the panel and precast elements as separate one-way panels is common (except for $2 \mathrm{~K}$ ceilings [12]), only in special cases such as the presence of forces concentrated on one of the panels, the possibility of taking over part of the load by adjacent panels is used. In the case of a beam model, the calculated displacement in a non-cracked state from the load scheme "J" (the slab was loaded by gravity over the entire surface with the value of $4.7 \mathrm{kN} / \mathrm{m}^{2}$ above its weight) was $12.1 \mathrm{~mm}$. The tests showed displacement equal to $3.5 \mathrm{~mm}$, measured at the edge of the central panels (panel No. 6). In the same case, the displacement of an uncracked monolithic slab, taking into account the reduction of stiffness resulting from the space filled with light concrete and the thickness of the slab at the joints was $2.2 \mathrm{~mm}$. The model of two-way work as for hollow core slabs, which can be used in the engineering practice of the TerivaPanel slabs, is a model with a hinge connection between panels (arching effects). However, due to the reinforcement of the support zones over a width of $1.0 \mathrm{~m}$ and the implementation of distribution ribs, the proper transverse work model will be subject to further numerical analyses. 


\section{Conclusion}

Tests carried out on the TerivaPanel slab showed that elements without the reinforcement of the joints between successive panels under short-term load did not exhibit excessive faulting. The maximum differences between adjacent sensors did not exceed $0.5 \mathrm{~mm}$. For the second stage of tests, under long-term loading, this difference shall be a maximum of 1.0 $\mathrm{mm}$. Deflection characteristics indicated the cooperation of panels in taking over surface loads. Under the influence of long-term loading, displacements were almost three times larger compared to displacements obtained from short-term loads. Observation of the bottom surface of the slab showed that under the influence of short and long-term loading no cracks appeared.

The values of displacements measured from field tests and calculated according to the linear-elastic model indicate the two-way nature of the work of the slab under the short-term load. The issue of spatial work of panel structures will be the main goal of further research and analysis. In particular, the focus will be on the work (behaviour) of the joint between panel elements depending on its design and loads (concentrated, cyclically variable and longterm). At the end of long-term measurements after 12 months, an increase in loads is planned, leading to cracking and destruction of the slab. After testing, visual inspection of the joints between panels (on core samples) and cracks on the upper surface of the slab (after removing the load) will be performed.

\section{References}

1. Ł. Drobiec, Stropy Vector. Koncepcja, ksztattowanie, projektowanie, wykonawstwo, Wydawnictwo Politechniki Śląskiej (2018).

2. A. Ajdukiewicz, J. Mames, Konstrukcje $z$ betonu sprężanego, Stowarzyszenie Producentów Cementu (2008).

3. A. Kisiołek, Rynek systemów stropowych w Polsce. Analiza wybranych rozwiazań na przestrzeni lat 2015-2016, Wydawnictwo Wyższej Szkoły Społeczno-Ekonomicznej w Środzie Wlkp. (2017).

4. W. Derkowski, New solution for prefabricated floor slabs, Cem. Wapno Beton 5, 372 (2019).

5. S. Han, J. Jeong, H. Joo, S. Choi, S. Choi, K. Kim, Flexural and shear performance of prestressed composite slabs with inverted multi-ribs, Appl. Sci. 9, 4946 (2019).

6. J. Song, S. Kim, Elliott, H. Lee, H. Kwak, Load distribution factors for hollow core slabs with in-situ reinforced concrete joints, Int. J. Concr. Struct.Mater. 3, 63 (2009).

7. W. Starosolski, Konstrukcje żelbetowe wedtug Eurokodu 2 i norm zwiazanych Tom 2, Wydawnictwo naukowe PWN (2016).

8. W. Starosolski, XVI Konferencja Naukowo-Techniczna „Jadwisin 98” - Beton i prefabrykacja, 2, 235 (1998).

9. W. Derkowski, P. Skupień, About the possibility of continuity of floor slabs with prestressed hollow core elements, Konferencja Naukowo-Techniczna Konstrukcje Sprężone, 79 (2018).

10. W. Derkowski, M. Surma, Shear capacity of prestressed hollow core slabs on flexible supports, Techn. Trans. Civ. Eng. 2-B (2013).

11. Konbet, Strop TerivaPanel, instrukcja montażu, składowania i transportu, Konbet Poznań (2019).

12. K. Gromysz, Stropy, belki i ściany zespolone typu beton - beton, XXV Warsztaty Pracy Projektanta Konstrukcji, Gliwice-Szczyrk, 1, 353 (2010). 